\title{
Mathematical education at Kryvyi Rih State Pedagogical University: history, analysis of achievements and prospects of development
}

\author{
Tetiana Kramarenko*, Volodymyr Korolskyi, and Dmytro Bobyliev \\ Kryvyi Rih State Pedagogical University, 54 Gagarina Ave, Kryvyi Rih, 50086, Ukraine
}

\begin{abstract}
The research deals with development of mathematical education at Kryvyi Rih State Pedagogical University (KSPU). The goal and objectives of the research include distinguishing and characterizing basic stages of formation and development of KSPU's mathematical education, informing about the state of teaching, methodological, scientific and research activity, and defining prospects for developing the Department of Mathematics and Methods of its Teaching in future. By stages of developing mathematical education at KSPU, the authors mean periods of its 90 -year development noted for certain peculiarities of organization and methods of training Mathematics teachers. Teaching, research and life dedicated to people are criteria that form the basis for determining basic stages in the Department of Mathematics' development. A special edition Mathematical Education in Kryvyi Rih Pedagogical University: Personality Dimension was issued to honour the 90th anniversary of the Department of Mathematics after analyzing information from the University archive, museum and accessible personal data of Mathematics teachers - University teachers, graduates and researchers. The data also concern their publications in ORCID and Google Scholar databases, the University repository, etc. There are characterized basic stages of developing mathematical education in the educational institution and its research trends.
\end{abstract}

\section{Problem statement}

From $60 \%$ to $90 \%$ of Mathematics teachers from Dnipropetrovsk region schools are graduates of Kryvyi Rih State Pedagogical Institute/University. During 90 years of its existence, a corps of highly professional teachers has been formed developing children education aimed at building the foundation for their further life success. As Ya. V. Shramko points out, teaching research, and life dedicated to people are priorities of a tertiary pedagogical institution [1]. Considering the fact that the teacher's role implies not only transmitting knowledge, but also forming the pupil's personality, the significance of a pedagogical university for those who used to go and go to region schools is evident.

\section{Analysis of publications}

V. N. Soloviev highlights some issues of development history of the Faculty of Physics and Mathematics in his paper dedicated to the $70^{\text {th }}$ anniversary of Kryvyi Rih State Pedagogical Institute [2]. V. P. Rzhepetskyi presents some important stages of forming the Department of Physics and Methods of its Teaching as well as characteristics of main research trends on the University site [3]. Works by I. S. Mintii, S. O. Semerikov, V. N. Soloviev reflect the 25-year history of the Department of Computer Science and Applied Mathematics [4]. The given paper deals with scientific, teaching and guiding work, the teaching staff, students' training and job placement and the Department's prospects.

To honour the $85^{\text {th }}$ anniversary of the University establishment, the scientific library has prepared the bibliographic list Academic and Intellectual Centre of Dnipropetrovsk Region [5] that presents materials from the library fund documents, the historical museum of Kryvyi Rih State Pedagogical Institute and accessible electronic resources.

Yet, the problem of developing mathematical education at Kryvyi Rih State Pedagogical University is not studied to the fullest in the mentioned papers.

\section{The research goal and objectives}

The research aims at singling out and characterizing basic stages of forming and developing mathematical education at Kryvyi Rih State Pedagogical Institute / University in order to inform about the state of teaching, guiding and research activity and prospects of the Department of Mathematics and Methods of its Teaching in future.

\section{Main material}

T. H. Kramarenko prepared a specialized edition Mathematical Education at Kryvyi Rih Pedagogical University: Personal Dimension dedicated to the $90^{\text {th }}$ anniversary of the University and the Department of Mathematics [6]. The book contains materials from the University archive, accessible data from University

\footnotetext{
* Corresponding author: kramarenko.tetyana@kdpu.edu.ua
} 
teachers', graduates', and researchers' personal pages as well as data on their research papers according to ORCID and Google Scholar databases, the University repository, the National Library of Ukraine named after V. I. Vernadskyi, etc. There are data on present-day teachers of the Department of Mathematics and Methods of its Teaching as well as on the pioneers of mathematical education at this educational institution. Those are wellknown graduates who excelled at pedagogical activity including researchers, Mathematics and Computer Science teachers, excellent workers of Ukrainian education, the best school principals of Dnipropetrovsk region, and gifted young people who have chosen to be teachers. The edition is aimed at popularizing scientific and pedagogical experience of Kryvyi Rih region's educators - graduates and workers of the Department of Mathematics and Methods of its Teaching, enhancing the prestige of teaching Mathematics, Physics and Computer Science, spreading ideas of self-education and selfimprovement in profession, theoretical and methodological foundations of implementing innovative technologies into Mathematics training. Short biographical reports, data on basic scientific and methodological activity trends are to orient readers towards choosing their own personal trajectory of professional growth.

Let us provide a short description of basic stages of developing mathematical education at the educational institution.

\subsection{Stage 1, 1930-1941}

In 1930, the Department of Physics and Mathematics was founded at Kryvyi Rih Institute of Vocational Education to teach a series of physical and mathematical subjects. Since then, history of the Faculty of Physics and Mathematics has started. In 1933, the Institute was transformed into the Pedagogical one and the first Mathematics teachers graduated in 1934. They acquired a wide range of knowledge and skills. 29 subjects including 18 field-related ones were taught at that time.

Such well-known mathematicians as L. A. Kareta, V. Boryshkevych and V. V. Sakk had been teaching in the early years of the Institute functioning [7]. Little is known about that period as part of the archive was lost in the war years. Professor L. V. Kareta taught in about 1933-1936. Besides, he was one of the founders of higher vocational education in Kryvyi Rih region working at the research sector of Kryvyi Rih Ore Mining Institute, the activity of which dealt with ore mining systems and search for efficient ways of mineral mining under certain conditions [7].

In 1936, after graduating from Dnipropetrovsk State University with an honour, B. M. Yakhnin (Speciality Mathematics Teacher) was placed to work at Kryvyi Rih State Pedagogical Institute [6, p. 133]. He started as a department assistant with a 480-hour yearly time sheet, but from 1938, he had been working as Dean of the Faculty of Physics and Mathematics and a senior teacher of the Department of Mathematics.

V. P. Zapolskyi worked as a Mathematics University teacher from September 1934 to 1935 and later on after a short pause until August 1941 [6, p. 62]. Having a 10-year experience of working at school, Zapolskyi taught methods of teaching Mathematics.

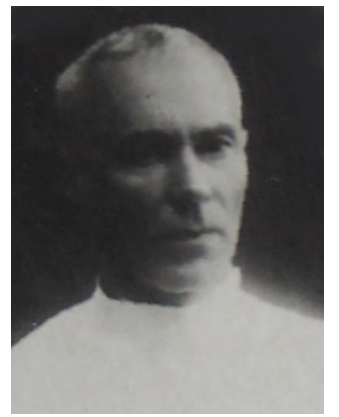

Fig. 1. Professor L. V. Kareta.

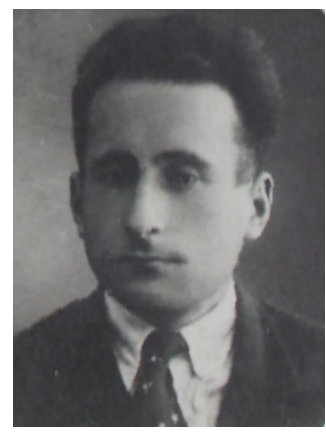

Fig. 2. Associate Professor B. M. Yakhnin.

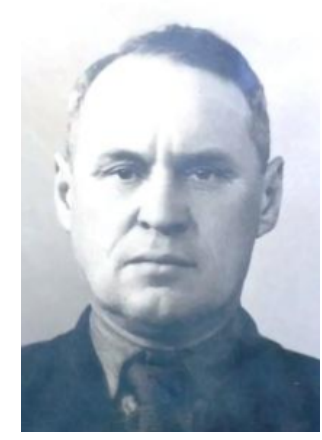

Fig. 3. V. P. Zapolskyi.

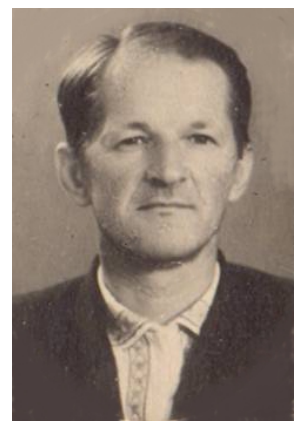

Fig. 4. Associate Professor F. K. Kosyk.

In 1939-1941, F. K. Kosyk was Head of the Department of Mathematics [6, p. 78]. In April 1941, Fedir Kalenykovych defended his Candidate's thesis in Physical and Mathematical Sciences Green Functions for Higher Order Operators at Kharkiv State University and 
was awarded a scientific degree of Associate Professor of Mathematics confirmed by the Higher Attestation Commission on March 27, 1943. At that time he had six research, papers two of which were published.

Teaching and devotion were priorities of Stage 1 of the Department development.

\subsection{Stage 2, 1944-1972}

In 1944-1945, 1947-1951, and 1953-1955, Candidate of Physical and Mathematical Sciences F. K. Kosyk, was Head of the Department of Mathematics. In 1945-1947, Candidate of Physical and Mathematical Sciences A. A. Markov, was temporarily in charge of the Department of Mathematics. In 1955-1959, V. P. Zapolskyi, a senior teacher, presided as Head of the Department.

B. M. Yakhnin became his successor. In 1959-1972, he was acting as Head of the Department and in 1962 he was appointed as such on a competitive basis. Working at the Institute, Yakhnin taught courses in Mathematical Analysis and Theory of Functions, conducted special seminars and was in charge of a students' Mathematics Circle. In 1963, Yakhnin defended his Candidate's thesis and became Candidate of Physical and Mathematical Sciences. As a researcher, he worked on the issue Investigation into Approximation of Functions on Classes by Means of Orthogonal Function Systems in the field of the constructive theory of functions. He had a number of research papers on Mathematics and teaching and guiding manuals for students, some of which being published in Journal of Higher Educational Institutions and Achievements of Mathematical Sciences including Studying the Upper Limit of Fourier-Valee-Poussin Totals by Means of Orthogonal Polynomials; Investigation into Some Processes of Function Approximation on Classes of Fourier-Valee-Poussin Totals According to Jacobi Polynomials; On FourierValee-Poussin Totals for an Aperiodical Case and Poussin-Abel Totals as an Approximation Toolkit.

In 1950, after graduating from the Faculty of Physics and Mathematics with distinction with a degree in Mathematics, M. P. Khoroshko [6, p. 130] was appointed Assistant of the Department of Mathematics and from 1954, he worked as a senior teacher. Later, he was chosen Dean of the Faculty of Physics and Mathematics. He upgraded his skills at Moscow State University and studied at Dnipropetrovsk State University as a postgraduate student. In 1969, Khoroshko defended his Candidate's thesis and got a Candidate degree in Physical and Mathematical Sciences. In 1974, he became Associate Professor of the Department of Mathematics (the course of Theory of Functions and Functional Analysis). Khoroshko is an author of almost 20 published research papers in Mathematics including those on uniform approximation of continuous functions by polynomials according to the Haar system; some experimental problems associated with approximation; assessment of the upper limit of Fourier coefficients on some classes of Haar, Walsh and Rademacher functions.

On the stage until 1972, along with the University restoration, we can mention researches into Mathematics as a leading type of activity of the Department.

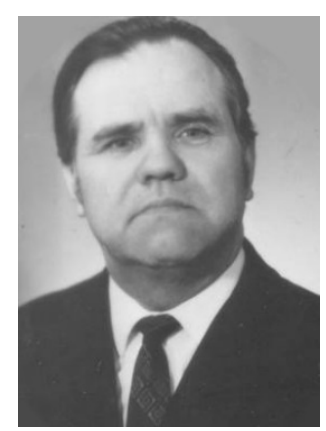

Fig. 5. Associate Professor M. P. Khoroshko.

It is worth noting that in this period, the Department was engaged into issues of approximating functions by polynomials in various spaces. B. M. Yakhnin started that work in close cooperation with scholars from Dnipropetrovsk State University of the Order of the Red Banner named after the $300^{\text {th }}$ Anniversary of UkraineRussia Reunion. The Department worked closely with Mykola Korneichuk (1920-2003), Academician of the National Academy of Sciences of Ukraine, a well-known Ukrainian mathematician, a pupil of Serhii Nikolskyi, Academician of the Academy of Sciences of the USSR. At that time, much work was done including the first results immediately published in a respectful Soviet scientific journal Achievements of Mathematical Sciences [8]. The paper proved dependency between sequences of Lebesgue functions $L_{n}^{(\alpha, \beta)}(x), n \in \mathbb{N}_{0}$ that determined the exact upper limit of expanding $f(x)$ functions from $C_{[-1,1]}$ space according to Jacobi sequences $J_{n}^{(\alpha, \beta)}(x), n \in \mathbb{N}_{0}$ :

$$
\left\{\begin{array}{c}
L_{n}^{\left(\frac{1}{2},-\frac{1}{2}\right)}(x)=L_{n}^{\left(-\frac{1}{2},-\frac{1}{2}\right)}(x)+O\left\{\frac{\left|\sin \left(n+\frac{1}{2}\right) \arccos x\right|}{\sqrt{1-x}}+1\right\}, \\
L_{n}^{\left(\frac{1}{2}, \frac{1}{2}\right)}(x)=L_{n}^{\left(-\frac{1}{2},-\frac{1}{2}\right)}(x)+O\left\{\frac{|\sin n \arccos x|}{\sqrt{1-x^{2}}}+1\right\},
\end{array}\right.
$$

where $n \rightarrow \infty$ i $O(1)$ is a value uniformly limited as to $x$ and $n$.

This work is still relevant today as it is referenced in articles from well-known mathematical journals in 2015 and 2016. This paper has not become passed today as it was referred to in many famous mathematical journals in 2015 and 2016.

Yakhnin established similar regularities for Lebesgue functions while assessing a Jacobi polynomial series expansion with weight of $P(x)=\sqrt{\frac{1+x}{1-x}}$ and that of P. L. Chebyshov polynomials [9].

That work was performed in cooperation with the Department Associate Professors M. P. Khoroshko and O. I. Polovyna.

Khoroshko [10] built effective approximations for class functions $H_{\omega}^{L}, H_{\omega}$ i $H_{V}$, by Haar polynomials by means of $L$ matrix and obtained evaluation of built approximations. This paper is still topical nowadays as it was referred to in 2006 and 2016.

Polovyna was engaged in approximating functions by algebraic polynomials [11]. The mentioned research was 
highly appreciated and supported by A. M. Kolmohorov, Academician of the Academy of Sciences of the USSR.

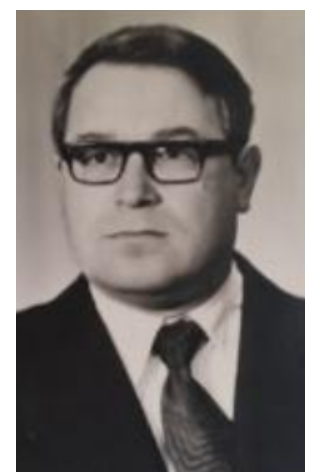

Fig. 6. Associate Professor O. I. Polovyna.

\subsection{Stage 3, 1972-1979}

As V. N. Soloviev indicates [2], the Faculty reached its climax in the 1970s-1980s. At that time, Specialities Physics and Mathematics and Mathematics both involved five student groups, each including students taking correspondence courses. In 1972, the $1^{\text {st }}$ All-Union Conference on Problems of Diffusion and Defect Formation in Solid Bodies was held at the Department. In 1975, a new research trend appeared - Computer Modeling of Defects in Crystals - followed up with regular conferences of All-Union scientific status. Professor A. E. Kiv, Doctor of Physical and Mathematical Sciences, the research supervisor of the seminar, became a laureate of State prizes of the USSR and the Ukrainian SSR. The Faculty departments conducted theoretical researches into physics of semiconductors, physics of solid bodies, theoretical and applied mechanics, methods of teaching Mathematics and Physics in cooperation with research institutes of Kryvyi Rih, Dnipropetrovsk, Kyiv and Moscow.

In 1975, the Department of Mathematical Analysis separated from the Department of Mathematics. Such Candidates of Physical and Mathematical Sciences, Associate Professors as B. M. Yakhnin, M. P. Khoroshko and O. I. Polovyna (Head of the Department in 19721982) worked there. Those researchers were engaged into various investigations including those in cooperation with the research school of M. P. Korneichuk, Candidate and later Doctor of Physical and Mathematical Sciences.

I. O. Polovyna was an author of a number of research papers in Mathematics, took an active part in scientific conferences and was in charge of scientific seminars on the theory of function approximation, variation calculus, linear programming and wrote several textbooks [6, p. 96]. In 1972-1977, he worked on the issue Approximation of Functions Continuous over the Interval by Polynomials considered as his Doctor's thesis.

In the same years, the Department of Mathematics comprising B. H. Druz (Head of the Department till 1976), S. V. Utkina, L. S. Naryshkina, N. V. Bohatynska and others enhanced their researches into the problems of pedagogics and methods of teaching Mathematics. In 1972, B. H. Druz defended his Candidate's thesis and got his Candidate of Pedagogical Sciences degree in methods of teaching Mathematics. He published his papers in journals specialized in methods of teaching Mathematics and, in 1976, got a degree of Associate Professor of the Department of Mathematics (the course of Methods of Teaching Mathematics).

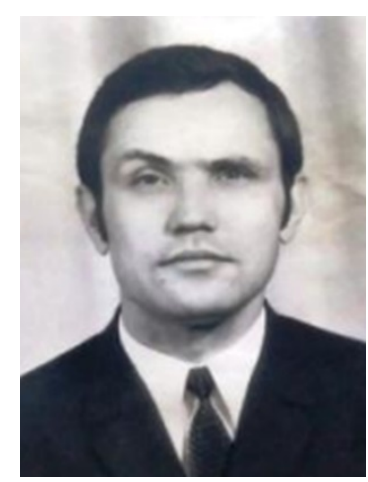

Fig. 7. Associate Professor B. H. Druz.

From April 1976, S. V. Utkina acted as Head of the Department of Mathematics, and from September of 1977 till September 1982, she was appointed such on a competitive basis. In that period, the Department staff was working on the integrated multi-authored theme Teaching Mathematics in Forms 4-10 of the Secondary School under the New Programme.

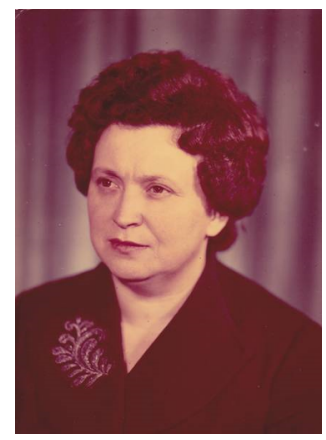

Fig. 8. Associate Professor S. V. Utkina.

Besides teaching and research in the field of Mathematics in particular, the Department's activity was focused on life dedicated to people. O. I. Polovyna used to deliver lectures on scientific and popular topics for secondary school teachers and pupils including the issues of applying Mathematics to Physics. The Department established a theme-based workshop to provide methodological support to school teachers of Kryvyi Rih.

\subsection{Stage 4, 1979-1992}

In 1979, a well-known Mathematics methodologist H. P. Bevz came to Kryvyi Rih State Pedagogical Institute to deliver lectures on methods of teaching Mathematics for Mathematics students. He was the Institute graduate and after finishing the postgraduate course, he worked as a senior teacher of the Department of Mathematics. Bevz was a renowned personality in the field of teaching Mathematics and a theme-based workshop was arranged at the Institute for the Institute staff from both departments of Mathematics as well as 
those of Pedagogy and Physics. In 1986, the assistant of the Department, L. O. Chernykh defended her Candidate's thesis and got a Candidate of Pedagogical Sciences degree under the supervision of H. P. Bevz (Improvement of Methods of Explaining Geometrical Concepts and Theories for School Plane Geometry Course). The scientific school of H. P. Bevz continued enhancing the Department's potential through conducting researches into methods of teaching Mathematics. A great number of the Department teachers including S. H. Shyperko and O. V. Vikhrova were the pupils of Bevz while studying at the post-graduate course.

When P. I. Shevchenko became Rector of Kryvyi Rih State Institute, the teaching staff's research potential greatly increased. Shevchenko got his Candidate of Pedagogical Sciences degree when he was Head of the Education Department in Kryvyi Rih Council. Young professionals of the Institute became more engaged into researches while studying at post-graduate courses in Kyiv and other scientific centres, that fact increasing the number of Candidates and Doctors of Sciences working at the Institute. P. I. Shevchenko focused professionals' attention on application of Mathematics to inter-subject links of field-specific subjects, especially those studied by future teachers of production-type service work [8].

In 1981, the Department senior teacher S. V. Utkina defended a Candidate's thesis in Pedagogical Sciences (Methods of Forming Geometrical Concepts at 8-year School through the Element System-Based Approach).

Candidate of Pedagogical Sciences, Associate Professor A. L. Zhokhov contributed much to enhancing investigations into methods of teaching Mathematics. He was appointed Head of the Department of Mathematics on a competitive basis in 1982-1990. Among researchers of Kryvyi Rih State Pedagogical Institute who successfully defended their Candidates' theses supported by A. L. Zhokhov, one can mention I. F. Safir (Enhanced Efficiency of Students' Mastering Algebra on the Basis of Structuring Training Materials (Incomplete Secondary Education), 1984), A. M. Drozdov (indicated in the minutes of the Department meeting concerning A. L. Zhokhov), A. M. Kapinosov (Methods of Forming Skills of Providing Arguments while Studying Mathematics in Forms 5-6, 1988), etc. A. L. Zhokhov delivered lectures and conducted seminars on methods of teaching Mathematics, Algebra and Theory of Numbers, Mathematical Analysis, Mathematical Logics and History of Mathematics.

The mentioned stage of the Department history is noted for enhanced researches into methods of teaching Mathematics.

From 1980, Candidate of Physical and Mathematical Sciences (Speciality Functional Analysis and Theory of Functions) V. H. Filipenko started working as Associate Professor of the Department.

In 1982-1992, Associate Professor, a 1961 University graduate P. I. Ulshyn headed the Department of Mathematical Analysis. In 1971-1974, P. I. Ulshyn was a post-graduate student of the Institute of Mechanics of the Academy of Sciences of the Ukrainian SSR. In 1981, he defended a Candidate's thesis Peculiarities of Movement of a Thread of Varied Length Conditioned by Non-Linear
Properties, (Speciality Dynamics, Strength of Machines, Devices and Apparatuses) at the Institute of Machine Building Problems of the Academy of Sciences of the Ukrainian SSR.

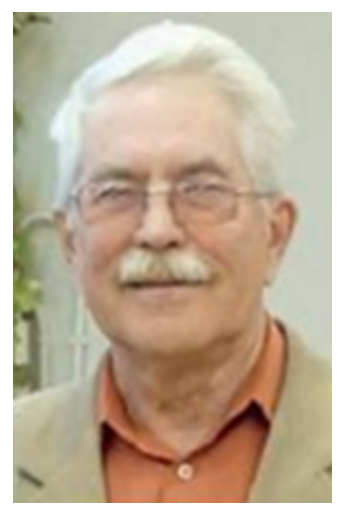

Fig. 9. Professor A. L. Zhokhov.

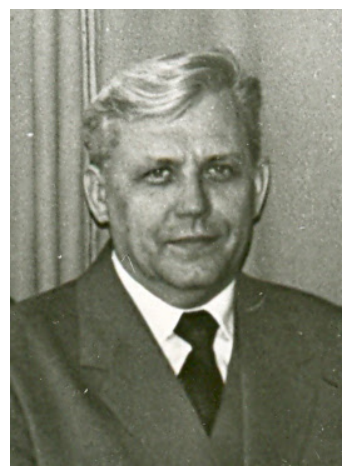

Fig. 10. Associate Professor P. I. Ulshyn.

1979-1992 are characterized by enhanced potentials of the Department of Mathematics due to the staff transferred from Kryvyi Rih Research Ore Mining Institute and the Laboratory of Mathematical Research Methods at the Research Institute Rudventyliatsiia which was transformed into the All-Union Research Institute of Labour Safety in Mining in 1972. In 1976, V. V. Korolskyi began working as an assistant and then a senior teacher and Associate Professor of the Department of Mathematical Analysis [12]. Candidate of Technical Sciences H. M. Shevtsova, started working as a senior teacher and Associate Professor in 1987. In 1987, V. V. Petrov, after working as an assistant (Speciality Computer Science and Computing Machines), took the post of the leading specialist of this course, Associate Professor V. N. Soloviev, who was sent away to take a year internship. In September 1988, the Department senior teacher chosen on a competitive basis, Candidate of Technical Sciences M. M. Hudymenko taught Algebra and Theory of Numbers and later became Associate Professor of the Department.

In 1986, O. I. Oleinikov began working as a senior teacher at the Department of Mathematical Analysis. While working at the Department, he accomplished his Candidate's thesis Rheological Ratios for Isotropic Media with Dilatancy and Internal Friction and Solution of some Problems. He successfully defended his thesis for a degree of Candidate of Physical and Mathematical 
Sciences in 1989 and developed his own courses - Convex Analysis, Geometrical Transformations and Symmetry and Mathematical Modeling.

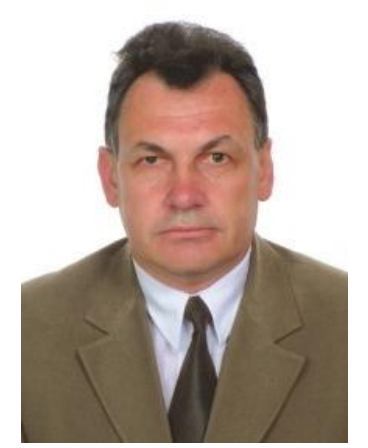

Fig. 11. Professor O. I. Oleinikov.

O. I. Oleinikov [13] proved the theory of unity of a solution for the model of heterogeneous-elastic material for geometrically linear arrangement of the boundary value problem of the elasticity theory on the basis of precise solution of inequalities of local convexity of elastic potential and stableness and established necessary and sufficient conditions for the stableness postulate to build the model. He analyzed unity and stableness conditions for an individual case - the model of loose material - and built their geometrical interpretation. O. I. Oleinikov was engaged into implementing the method of boundary elements into calculating the stressstrain state of rocks.

Analysis indicates that the Department's potential increased due to contribution of Candidates of Technical Sciences whose scientific interests were associated with application of mathematical modeling to mining and adjacent sciences. In particular, while working as an assistant of the Department of Mathematical Analysis from 1979 and a senior teacher from 1982, V. N. Soloviev prepared and, in 1981, defended his Candidate's thesis and got a Candidate of Physical and Mathematical Sciences degree. At that time, he participated in arranging All-Union workshops on computer defects in crystals (Kryvyi Rih, 1975, 1977, 1982), supervised students' research work, developed curricula on Numerical Mathematics and worked out instructions for doing laboratory works.

\subsection{Stage 5, 1992-1997}

As rapid informatization of society conditioned the need for highly-qualified Computer Science teachers and engineers, the Institute introduced such new specialities as Mathematics and Computer Science (at the end of the 1980s), Physics and Computer Science (the mid-1990s) and Computer Science (2001). In 1992, the Department of Computer Science and Applied Mathematics was created. V. N. Soloviev became the Department Head and defended his Doctor's thesis in Physical and Mathematical Sciences in 1993. S. O. Semerikov, I. O. Teplytskyi, N. A. Kharadzhian and others defended their Candidates' theses in Pedagogical Sciences under the supervision of Doctor of Physical and Mathematical Sciences V. N. Soloviev.
In 1992-1994, the Department of Mathematical Analysis was headed by Candidate of Physical and Mathematical Sciences, Associate Professor O. I. Polovyna. From 1990 to 1994, Candidate of Pedagogical Sciences, Associate Professor L. O. Chernykh was the Department Head. In 1994, the Department of Mathematical Analysis and that of Mathematics merged under the supervision of Candidate of Physical and Mathematical Sciences O. I. Olienikov, who defended his Doctor's thesis in Physical and Mathematical Sciences at the Institute of Mechanics of the National Academy of Sciences of Ukraine in 1995. He also published a monograph based on his research in 1999. His scientific contribution accounted for 58 papers including 16 published abroad.

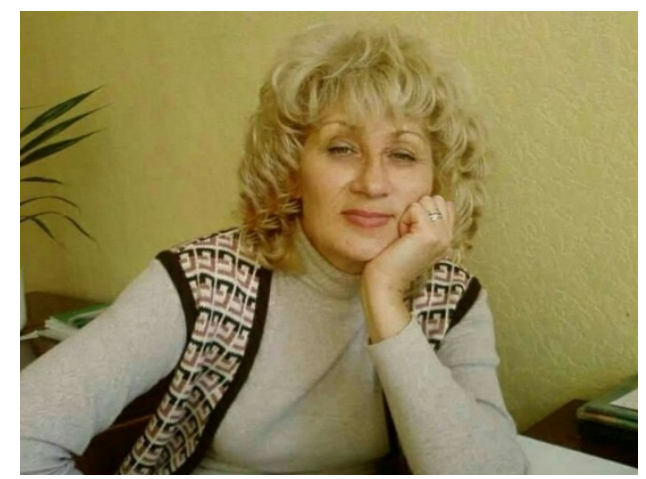

Fig. 12. Associate Professor L. O. Chernykh.

M. O. Rashevskyi, who graduated from Kryvyi Rih State Pedagogical Institute in 1988, conducted his researches at the Department of Mathematics followed by a successfully defended Candidate's thesis in Physical and Mathematical Sciences (Speciality Differential Equations) in 1995. His further scientific interests were associated with the theory of probability and other fields of Mathematics.

In 1997, O. V. Vikhrova defended her Candidate's thesis Systematization and Generalization of Pupils' Mathematical Knowledge while studying Algebraic Structures and got her Candidate of Pedagogical Sciences degree (13.00.02 Theory and Methods of Teaching. Mathematics).

\subsection{Stage 6, 1997-2011}

In 1997-2011, Candidate of Technical Sciences, Professor V. V. Korolskyi was Head of the Department of Mathematics at Kryvyi Rih State Pedagogical Institute/University.

In 1997-2002, there were three research trends in the Department activity - mathematical models and methods of heterogeneous elasticity (supervised by Doctor of Physical and Mathematical Sciences O. I. Oleinikov); methods of enhanced teaching of Mathematical Analysis, Geometry and Higher Mathematics (supervised by Candidate of Technical Sciences, Professor V. V. Korolskyi); development of methods for training Mathematics teachers working under educational humanitarization conditions (supervised by Candidate of Pedagogical Sciences, Associate Professor L. O. Chernykh). 


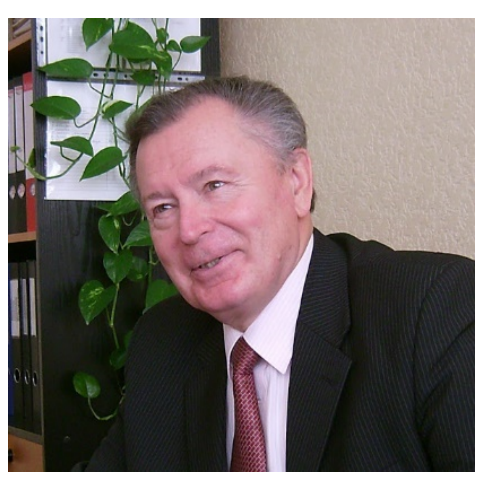

Fig. 14. Professor V. V. Korolskyi.

In this period, there were two defended Candidates' theses including that by I. V. Lovianova - Formation of Senior Schoolchildren's Intellectual Skills through Studying Natural Sciences in 2006 (13.00.09 - Theory of Teaching) supervised by Doctor of Pedagogical Sciences, L. V. Kondrashova.

In 2003-2010, the Department of Mathematics staff worked on the integrated theme Students' Independent Work in Studying Mathematical Subjects under CreditBased Module Learning supervised by Candidate of Technical Sciences, Professor V. V. Korolskyi.

In 2010, Candidate of Pedagogical Sciences, Associate Professor L. O. Chernykh, Candidate of Technical Sciences, Associate Professor P. I. Ulshyn, Candidate of Pedagogical Sciences, Associate Professor I. V. Lovianova, the senior teacher L. P. Korolska, the senior teacher S. H. Shyperko worked on the integrated theme of the Department, in particular, Stage 4 Control and Evaluation of Students' Knowledge in Mathematics under Credit-Based Module Learning.

Topicality. Under Credit-Based Module Learning, the problem of control and relevant evaluation of academic results of individual students is of great importance. After studying practices of similar departments of universities from Ukraine, Belarus and Russia accompanied by accumulation of the Department staff's experience, there appeared a necessity to systematize scientific and practical results of organizing, controlling and assessing mathematical knowledge under current conditions of higher pedagogical education.

Module and rating control and evaluation aimed at introducing students' independent work through developing their self-control and self-evaluation skills are becoming urgent.

The research tasks include:

- studying and introducing various mathematical models of assessing students' knowledge in Mathematical subjects into the Department activity;

- arranging and expanding potentials of various types and forms of control over training quality under the rating evaluation system to assess students' results in Mathematics;

- studying potentials and efficiency of conventional and modern means of making control and measuring devices for each mathematical subject;

- developing general requirements to form rating evaluation for the Department subjects considering varied methods of accumulation of grades in different mathematical subjects.

Research methods: theoretical analysis of scientific, psychological, pedagogical, teaching and guiding literature on issues under investigation, analysis and generalization of pedagogical experience; synthesis of achievements in didactics and methods of teaching Mathematics at higher educational institutions.

Theoretical research results:

1. There are developed general principles of forming rating for the Department subjects (informative content, systematicity, consistency, transparency, consideration of various activity types).

2. The role and functions of the rating evaluation system of academic results in fundamental mathematical subjects are determined:

- possible application of various control types and forms; - encouragement of students' training and cognitive activity due to step-by-step evaluation of various work types;

- motivation of students for systematic work during the term;

- increased objectivity of final (examination) evaluation;

- reduced significance of random factors;

- uniform distribution of student-teacher load.

3 . The system (scheme) of regulating control steps to form students' rating evaluation based on the concept of training and rating units is developed.

Practical research results:

1. Under the rating-based module learning, teachers implement various assessment modes to evaluate students' knowledge in mathematical subjects - models considering task parameters, performance time, acquisition levels; models based on probability criteria; models based on the theory of fuzzy sets.

2. There is created methodological and computer-assisted support to arrange and control students' results in mastering the Department's subjects.

3. The elaborated structure of rating evaluation of students' mathematical results enables monitoring students' individual academic trajectories (discussion at the Department meetings twice a term).

Testing of research results:

1. The research results were implemented into the Department activity: knowledge control is based on a weighted total of students' grades by various methods.

2. The research results of the integrated theme were reflected in some scientific and methodological papers and the Department teachers' reports at scientific conferences.

It is the Department's tradition to participate in organizing the international scientific and practical conference Theory and Practice of Fundamental Subjects at Higher School that has been conducted since 2001 [14]. The Department of Mathematics staff works closely with the Department of Computer Science and Applied Mathematics. In this respect it is worth mentioning Candidate of Pedagogical Sciences I. O. Teplytskyi and Doctor of Pedagogical Sciences S. O. Semerikov (Theoretical and Methodological Basics of Fundamentalization of Teaching Informatics Subjects at Higher Educational Institutions, 2009). Cooperation 
concerns issues of introducing Information Technologies into Mathematics training, participation in scientific conferences on problems of ICT implementation in education, All-Ukrainian scientific and methodological workshops Computer Modeling in Education and international scientific and practical conferences Innovative Computer Technologies. Being an organizer of a number of international scientific and practical conferences, S. O. Semerikov focuses on creating highquality platforms for scientific discussions.

As a result of cooperation, a team of authors including V. V. Korolskyi, T. H. Kramarenko, S. O. Semerikov and S. V. Shokaliuk prepared a teaching manual Innovative Information and Communication Technologies in Teaching Mathematics (2009). In 2008, T. H. Kramarenko defended his Candidate's thesis (Formation of Schoolchildren' Personal Features of Under Computer-Oriented Learning of Mathematics) and got a Candidate's of Pedagogical Sciences degree (13.00.02 - Theory and Methods of Teaching. Mathematics) under the supervision of Doctor of Pedagogical Sciences, Professor, Active Member of the National Academy of Pedagogical Sciences of Ukraine M. I. Zhaldak. Teaching aids visualization during lectures and practical classes, in particular in Mathematics, allows students to understand the learning material better, to increase the applied orientation of learning and the communication competence both learners and teachers. One of the ways to improve the abstractions visualization in Mathematics is a pedagogically sound and appropriate application in the teaching the modern ICT. Report cleared out the integral computer-oriented approach. It in detail its use in the study of school course of Mathematics, directed on forming of personality qualities of student such as organizational, cognitive, creative; ones; criteria and levels of formed of personality qualities are specified.

\subsection{Stage 7, 2011-2019}

In 2011, the Department of Mathematics was transformed into the Department of Mathematics and its Teaching Methods. From that time till April 2019, the Department was headed by Candidate of Technical Sciences, Professor V. V. Korolskyi who was also an Honorary Figure of People's Education of Ukraine.

From January 2020, Candidate of Pedagogical Sciences, Associate Professor D. Ye. Bobyliev was chosen Head of the Department of Mathematics and Methods of Teaching on a competitive basis.

In the mentioned period, the Department staff conducted a series of researches, while one Doctor's thesis and five Candidates' theses were defended.

There were defended four theses in methods of teaching Mathematics (Speciality 13.00.02 - Theory and Teaching Methods. Mathematics), their results being implemented into future Mathematics teachers' training. In 2015, the Department Associate Professor I. V. Lovianova defended her Doctor's thesis in Pedagogical Sciences (Theoretical and Methodological Foundations of Teaching Mathematics at ProfessionOriented School) supervised by Doctor of Pedagogical Sciences, Professor N. A. Tarasenkova) [15].
The dissertation [15] is devoted to the problem of scientific substantiation of the theoretical-methodological bases of formation of professional orientation of the individual students in the senior profile school during their mathematical training, creating and implementing real learning process of methodical system of professionally oriented teaching mathematics. The dissertation is offered the concept of mathematical training of pupils of profile school which basic provisions are based on: the role of mathematical training in education; on the group of the principles, among which the classical didactic principles; the principles of profile training; the principles of mathematical training of seniors; the principles of design of process of training in mathematics at the profile school. Methodological tools of research of problems of profile differentiation of training are chosen: in historical aspect - the comparative approach (for comparison in the sphere of a diachrony and comparison of the phenomena removed spatially); general scientific approaches (system-structural, operational, axiological, semiotic, competence) to provide training, which ensures the formation and development of the individual pupil; task approach to teaching mathematics, which provides the organization of mastering the content of professionally directed training of mathematics profile school pupils through the introduction of a learning content professionally designed tasks; the state documents on updating and improvement of the content of mathematical education; the historical and modern tendencies of development of school mathematical education in the context of its profiling.

In 2017, the Department part-time assistant O. V. Ambroziak defended his Candidate's thesis (Methodological Foundations of Implementing a Competence-Based Approach in Teaching Linear Algebra for Future Informatics Teachers) supervised by Doctor of Pedagogical Sciences, Professor I. V. Lovianova.

In 2018, D. Ye. Bobyliev defended his Candidate's thesis (Methods of Teaching Functional Analysis for Future Mathematics Teachers) supervised by Doctor of Pedagogical Sciences, Professor I. V. Lovianova. Insufficient attention to the practice of applying numerical methods in the existing functional analysis manuals compiled for applied specialties can be explained by several circumstances. Firstly, the very ideology of functional analysis is tuned to the high abstractness of this section of mathematics. Secondly, the training trajectories of this discipline were structured at a time when computer technologies were still far from the leading role in education, and therefore, their connection to the educational process was not perceived as something natural and not burdensome. Thirdly, numerical methods are traditionally presented in a separate course of computational mathematics (or course of numerical methods) [16].

The approximation of the course of functional analysis to computational mathematics contributes to the continuity and coherence of vocational training. Perhaps this is even the only way to fully implement functional analysis in a pedagogical university. The convergence with computational mathematics should be such as to 
fully prove the theoretical fact to the number: to trace the projection of abstract ideas into the plane of numerical methods and to give an opportunity to immediately test methods in computational practice. Of course, the measure of this convergence should be reasonable, so that functional analysis does not lose its identity and is not substituted by the course of computational mathematics. To solve these problems, a scientific methodological research was conducted and a set of two textbooks was developed: a summary of lectures and a collection of tasks on functional analysis for pedagogical universities [16].

In 2014, I. S. Dereza defended her Candidate's thesis in Pedagogical Sciences (Organization and Pedagogical Conditions of Controlling Mathematics Students' Independent Work at Pedagogical University), Speciality 13.00.06 - Theory and Methods of Educational Management, under the supervision of Doctor of Pedagogical Sciences, Professor L. V. Kondrashova.

In 2017, K. V. Polhun defended her Candidate's thesis in Pedagogical Sciences (Organization of Inclusive Teaching of Physical and Mathematical Subjects for Handicapped Students at Higher Educational Institutions), Speciality 13.00.09 - Theory of Teaching) under the supervision of Doctor of Pedagogical Sciences, Professor Z. P. Bakum [17]. The report contains the results of theoretical and experimental research of the organization process of inclusive learning of physical and mathematical disciplines by students with disabilities in technical institutions of higher education. Psychological factors of organizing inclusive learning of physical and mathematical disciplines by students with disabilities in technical institutions of higher education are identified.

Dominant methodological approaches (individualoriented, competence-oriented, and systemic one) have been identified that contribute to the efficient organization of inclusive learning of physical and mathematical disciplines by students of the category under investigation in technical institutions of higher education, specific teaching principles have been determined. Forms, methods, techniques of teaching processes have been examined that ensure the formation of mathematical competence in students with special needs. The expediency and the necessity of using the research method of learning, the heuristic method, the method of problem statement, the method of projects, the method of learning by cooperation, the method of simulation of professional situations, as well as information and communication technologies along with adaptive ones have been proven.

It has been found that the mathematical competence of the student of a technical institution of higher education can be represented by a synthesis of the following components: motivating-values component, cognitive component, action-dominated component, and reflective one. In accordance with the structure of the mathematical competence of students, the relevant criteria (valuedorientation criterion, cognitive criterion, procedural criterion, evaluative and regulative one) and their indicators have been identified to determine the formation levels (low, medium, sufficient, high) of each of the components of that competence.

A functional and structural model of inclusive learning of physical and mathematical disciplines by students with disabilities in technical institutions of higher education has been developed, which requires creating a set of certain teaching conditions and contains four interrelated components: the target-oriented component, the contentoriented component, the operation-and-action-oriented component and the control-and-evaluation one.

The teaching and methodological materials developed during the study have been represented in the author's Guide called "Inclusive Learning of Mathematics in Institutions of Higher Education" and in the Methodology Recommendation on the use of electronic instructional and methodological package for higher mathematics under the conditions of inclusive learning [17].

In 2011, the Department of Mathematics and Methods of its Teaching in cooperation with the Department of Computer Science and Applied Mathematics conducted the All-Ukrainian scientific and methodological conference of young scholars Innovative Information and Communication Technologies for Teaching Mathematics, Physics and Informatics at Secondary and Higher Educational Institutions with the corresponding collection of papers published [18].

In 2009-2014, the Department staff worked on two integrated themes. One of them is Technology of Differential Teaching of Mathematics at Schools of General Education supervised by Candidate of Technical Sciences, Professor V. V. Korolskyi, Candidate of Pedagogical Sciences, Associate Professor A. M. Kapinosov.

The project executives were senior teachers N. V. Bohatynska, L. R. Korolska, H. M. Bilousova, Candidate of Technical Sciences, Associate Professor P. I. Ulshyn, Candidates of Pedagogical Sciences, Associate Professors T. H. Kramarenko, L. O. Chernykh and O. V. Vikhrova.

The research is aimed at theoretical substantiation of technology of theme-based level teaching of Mathematics, developing teaching and guiding support of the technology and testing efficiency of the implemented technology in teaching Mathematics at secondary schools.

In 2014, Stage 4 (finalizing and correcting) of the theme development was performed.

The research final results were three packages.

Package 1 Theoretical Substantiation of Differential Technology of Teaching Mathematics: there were substantiated content and organization-methodological principles and rules of designing, arrangement and implementation of theme-based level differential teaching of Mathematics; models for teaching multi-level pupils; benchmark characteristics of training levels in Mathematics in the form of multi-level criterion tasks and problems.

Package 2 Theoretical Procedures of Theme-Based Levelled Differential Teaching of Mathematics: there was description of the technology as a series of solving didactic problems, local technologies and the technology of basic lesson types.

Package 3 Methodological Toolkit of Theme-Based Level Differential Teaching of Mathematics: there were developed blocks of training tasks, control tasks, lesson plans, course books and teaching manuals for level teaching. 
The developed products were in electronic format. There were 3 published course books, five teaching manuals, 30 scientific and methodological papers eight of which were published in dedicated journals. There were also 25 qualification and 40 course papers written and defended.

Testing of the research results was performed through delivering lectures and conducting practical classes at advanced training courses for Mathematics teachers at Kryvyi Rih State Pedagogical University comprising 50 lectures at the University and 60 lectures at regional institutes of post-graduate education. There were conducted several scientific and methodological workshops for Mathematics teachers.

In 2015-2019, the Department of Mathematics and Methods of its Teaching staff worked on the integrated theme Theoretical and Methodological Foundations and Technologies of Implementing a Competence-Based Approach into Training of Mathematics Teachers supervised by Candidate of Technical Sciences, Professor V. V. Korolskyi. The theme was approved at the Department of Mathematics and Methods of its Teaching meeting, Minutes 11, 20 May, 2015. The research character was fundamental and applied.

I-II. Theoretical and Methodological Stage (January 2016-December 2017).

The stage was aimed at developing theoretical and methodological foundations of the technology of forming professional competences (basic, specific, partial) while studying content modules of mathematical subjects and courses of methods for teaching Mathematics.

The research tasks included:

1.Determining the role and the place of content modules of mathematical subjects (Mathematical Analysis, Algebra and Theory of Numbers, Geometry, Discrete Mathematics, Theory of Probability and Mathematical Statistics, Functional Analysis, Methods of Teaching Mathematics) in forming (developing, studying in depth) professional competences of future Mathematics teachers.

2. Determining tasks on the basis of content modules of subjects (see 1) relevant to developed professional competences.

3. Revealing peculiarities of methodological systems of teaching content modules being guided by the competence-based approach (result-oriented, organization- and content-based).

Theoretical results:

1. The role and the place of content modules of subjects in the framework of new curricula for Speciality Mathematics (Terms 1 and 2: Mathematical Analysis, Algebra and Theory of Numbers, Geometry) were determined.

2. Professional competences and basic professional tasks for forming field-specific competences were determined.

3.Peculiarities of methods for teaching content modules guided by the competence-based approach were partially ascertained.

The structure of teaching manuals to study content modules for the Department subjects during students' independent work was elaborated.
The research was in accordance with the aim and the tasks of the corresponding stage - development of theoretical and methodological foundations of forming professional competences in studying content modules of mathematical subjects and courses of methods of teaching Mathematics.

The research resulted in setting the role and the place of content modules studied in Term 1 while forming (developing studying in depth) professional competences and defining basic professional tasks relevant to competences, ascertaining peculiarities of methods of studying content modules guided by the competencebased approach.

Stage III: Applied (technological) (September 2017December 2018).

The research tasks included description of formation of professional competences, development of training and monitoring materials.

The research results included teaching and guiding manuals and reference books.

Stage IV. Reflexive (controlling and concluding): January - December 2019. Finalizing the Department theme. The research was aimed at developing methodological, theoretical and method-based foundations of the competence-based approach in Mathematics teachers training while studying mathematical subjects and courses of methods of teaching Mathematics.

The research topicality. The models of professional competences (scientific-subject and method-based) of Mathematics teachers were crude and underdeveloped as well as the method systems (objectives, content, organization and methods, monitoring) of module learning for mathematical courses and methods of teaching Mathematics based on the competence-based approach both on the theoretical and practical (technological) levels.

The research is aimed at analyzing the research results, correcting methods, developing recommendations, generalizing, systematizing data and preparing a monograph and teaching manuals.

In 2019, there were three monographs two of which were published in Ukraine and one - abroad, eight course books and teaching manuals, eight papers four of which were published in Ukraine and four - abroad The results of 2019 included three monographs, one of which published abroad, eight course books and teaching manuals; eight papers, four of which published abroad (Scopus and Web of Science databases) [19-24].

The published course books included Geometry (specialized level), Textbook for Form 10 of Secondary Schools by Professor I. V. Lovianova [25]; the revised edition of the teaching manual Mathematics. Integrated Edition for State Final Attestation and External Independent Evaluation by H. M. Bilousova, A. M. Kapinosov, and P. I. Ulshyn [26], the revised edition of the teaching manual for training future Mathematics and Computer Science teachers Innovative Information and Communication Technologies for Teaching Mathematics by T. H. Kramarenko, V. V. Korolskyi, S. O. Semerikov, S. V. Shokaliuk and M. I. Zhaldak (ed.) [27]. 
It was carried out the maintename of mathematics, proper theoretical and task material, in particular, for the deep study of mathematics, pedagogical programmatic facilities, computer-oriented methods and forms of studies, were considered principles of construction of the system of developing tasks. The methodical recommendations are developed in relation to the use GRAN1, GRAN-2D, GRAN-3D, DG, GeoGebra in an educational process. The results of pedagogical experiments confirm the efficiency of the offered components of the computer-oriented system methodical of studies [27].

S. O. Semerikov attributes Artificial Intelligence Education Applications, Applications in Education, Conversational User Interfaces, Blockchain in Education, Immersive Technology Design Thinking, CompetencyBased Education Platforms and Adaptive Learning Platforms to the main tendencies of using ICT in education. Since augmented reality technology already has an important place in innovative development, it can also have significant potential for implementation in Mathematics learning. That is why this technology needs more detailed study [28].

Because augmented reality is intrinsically linked to 3D-construction, its usage in conjunction with Dynamic Mathematics systems like GeoGebra, can significantly increase the level of visualization in Mathematics and enhance students learning. In addition, Augmented Reality can become a tool for enhancing STEM-based learning for students majoring in Mathematics and Computer Science [29-30]. At present, the use of augmented reality technology in teaching, including Mathematics, requires development, research, and testing.

Electronic academic courses based on the electronic management system MOODLE are widely applied to training Mathematics teachers.

The Department of Mathematics and Methods of its Teaching has been a vital and integral part of the Faculty of Physics and Mathematics of Kryvyi Rih State Pedagogical University since its founding. The department arranges training work at the Faculty of Physics and Mathematics as majors and at other departments as minors.

Annually the faculty welcomes school leavers and encourages them to apply for the area of expertise "Mathematics", as well as the following supplementary specialties: "Computer Science".

According to the staff division in the beginning of academic year 2019-2020 the department has 1 Doctor of Pedagogical Sciences, 8 Candidates of Sciences; 1 Professor, 4 Associate Professors.

Teachers of the Department of Mathematics and Methods of its Teaching carry out research work in accordance to the general plan of the department. The system of preparation of scientific and pedagogical staff actively functions at the department through postgraduate studies.

The department offers postgraduate studies in the following areas of expertise 13.00.02 - Theory and Methodology of Teaching the Mathematics.

The bachelor's degree program is designed to take four years to complete. The following courses are available at the faculty to obtain the Bachelor's degree: "Mathematical analysis" [22], "Complex analysis", "Functional analysis"[16], "Financial Mathematics", "Calculus", "Differential equations" [\&\&], "The basis of further Mathematics", "Methodology for teaching mathematics", "Analytical geometry", "Differential geometry", "Mathematical Logic", "Linear Algebra" [23], "Algebra and Number Theory", "Elementary Mathematics", "Discrete Mathematics", "Mathematic and statistic", "Information and communication facilities for teaching mathematics", "Probability theory and mathematical statistics", "Intel Training for the Future Course" seminars and special courses on Mathematics. The Master's degree requires completing an undergraduate degree. The faculty offers the following academic courses:, "Methodology for teaching Mathematics in the profile school", "Selected geometry questions", "History of development of mathematical education Higher Mathematics", "Methods of mathematical statistics in scientific research", etc. completion of these courses is awarded with the Master's.

The department provides a solid foundation for sustainable scientific development.

Faculty graduates become teachers of Mathematics and Computer Science. They are involved into scientific activities not only in Kryvyi Rih and Ukraine research establishments, but also in the leading foreign institutions abroad.

\section{Prospects of the Department's research activity}

The short-term prospect of the department involves improving scientific, methodological and information provision of training future Mathematics teachers as well as improving their qualification.

Nowadays, a university teacher's professional activity is shifting towards the informational space. There are many factors causing this including introduction of education assisting systems like Moodle. Innovative technologies and new training methods are being implemented into the educational system. Digitalization of education has become urgent.

Blended learning embracing digital distance technologies and contact teacher-student communication is becoming a well established practice. Blended learning is an educational technology, which combines traditional (face-to-face) training and elements of distance technologies (on-line training). Combination of these two forms of training provides for their equal significance in the training process. It should be noted that blended learning envisages considerable amount of students' independent work and their participation in building their own academic trajectories. It acquires specific significance in arranging future Mathematics teachers' training characterized by students' high governance and required development of independent training skills. For this reason, the Department is planning to conduct the research called Blended Learning Technology in Fundamental and Professional Training and Improvement of Qualification of Mathematics Teachers in 2020-2024. The research aims at developing, 
substantiating and testing the model of implementing the blended learning technology into Mathematics teachers' fundamental and professional training and improvement of their qualifications as well as finding ways of implementing the technology.

In the immediate future, the Department should adopt a systematic assessment of students' knowledge according to content-based modules for the relative subjects through using the system of controlling electronic academic courses in MOODLE and publish accumulated experience of work with under- and postgraduates in the form of teaching, guiding and research materials.

The mid-term prospect involves improvement of the academic and methodological activity of the department and gradual transition to the training and technological activity. In other words, the Department teachers should master the technological approach to training, develop models of professional knowledge and present training materials of the Department-related subjects as adaptive knowledge-oriented training technologies. At this stage of working on the research, the Department staff's activity should be aimed at developing theoretical principles of using MOODLE and investigating into opportunities to increase the Department's virtual intellectual potential through applying models of highly qualified specialists' professional knowledge. Scientific substantiation and experimental testing of economic efficiency of MOODLE application to training Mathematics teachers and improving their qualification is an important trend of the Department's activity. Basic mid-term tasks of the Department development include further improvement of the scientific school of methods for Mathematics training by increasing the number of postgraduates for Speciality 014.04 Secondary Education (Mathematics). Teaching and guiding aids developed at this stage should reflect results of testing blended learning technologies accompanied by experimental results published in research papers and monographs.

The final stage of working on the multi-authored research provides substantiation of application of the blended learning technology in the full cycle to training Mathematics teachers. While working at the mentioned research, the Department staff should focus on improving the material and technical support, increasing the number of printed and electronic papers (monographs, textbooks, teaching guides on subjects of fundamental and professional training of Mathematics teachers), improving the image of the Department in the Ukrainian scientific space, expanding contacts with foreign scientific organizations and educational institutions, and taking an active part in international scientific and research projects on educational problems.

\section{Conclusions}

The research considers basic stages of history of the Department, analyzes its main achievements. The Department's activity is aimed at implementing academic curricula of specialists training, re-training and enhancing their qualification, training scientific and pedagogical staff, elaborating a single concept of the academic content for the subjects taught at the Department, developing requirements and suggestions for upgrading the content and volume of curricula and preparing scientific and methodological support of the subjects. The Department is engaged into developing and implementing innovative academic technologies into the training process, conducting researches aligned with research trends of the University. Much attention is paid to cooperation with academic and research institutions of Ukraine and other countries. The Department staff participates in training, re-training and upgrading secondary school and University teachers' qualification.

\section{References}

1. Ya.V. Shramko, Misiya pedahohichnoho universytetu (Mission of the Pedagogical University) (2017),

https://kdpu.edu.ua/blogs/2017/10/03/misiyapedagogichnogo-universytetu/\#more-8. Accessed 28 Nov 2019

2. V.M. Soloviov, in Computer simulation and information technology in the natural sciences (KSPU, Kryvyi Rih, 2000), pp. 3-6

3. V.P. Rzhepetskyi, Istoriya kafedry fizyky ta metodyky yiyi navchannya KDPU (History of the Department of Physics and methods of its teaching KSPU) (2017), https://kdpu.edu.ua/fizyky-tametodyky-ii-navchannia/zahalna-informatsiia/prokafedru/102-istoriia-kafedry-fizyky-ta-metodyky-iinavchannia.html. Accessed 28 Nov 2019

4. I.S. Mintii, S.O. Semerikov, V.M. Soloviov, in Proceedings of the $V$ All-Ukrainian ScientificPractical Conference of Young Scientists "Scientific Youth-2017”, Kiev, 2017, ed. by O.M. Spirin, A.V. Yatsyshyn, pp. 167-171

5. O.M. Kravchenko (ed.), Osvitn'o-intelektual'nyy tsentr Dnipropetrovshchyny (do 85-richchya zasnuvannya Kryvoriz'koho pedahohichnoho instytutu DVNZ “Kryvoriz'kyy natsional'nyy universytet") (Kryvyi Rih, 2015), http://elibrary.kdpu.edu.ua/handle/0564/299. Accessed 28 Nov 2019

6. T.H. Kramarenko (ed.), Matematychna osvita $u$ Kryvoriz'komu pedahohichnomu: osobystisnyy vymir (Mathematical Education at Kryvyi Rih Pedagogical University: Personal Dimension) (Kryvyi Rih State. Ped. Univ., Kryvyi Rih, 2020), http://elibrary.kdpu.edu.ua/xmlui/handle/123456789 /3617. Accessed 08.02.2020

7. Ya.V. Shramko (ed.), Profesory Kryvoriz'koho pedahohichnoho (Professors of Kryvyi Rih Pedagogical) (Kryvyi Rih, 2015)

8. B.M. Yakhnin, Uspehi Mat. Nauk 13, 6(84), 207-211 (1958)

9. B.M. Yakhnin, Izv. Vysš. Učebn. Zaved. Matematika 1(2), 202-207 (1958)

10. M.P. Khoroshko, Mat. Zametki 6, 47-54 (1969)

11. N.P. Korneichuk, O.I. Polovyna, Dokl. Akad. Nauk SSSR 166, 281-283 (1966) 
12. H.M. Vinyar (ed.), Volodymyr Viktorovych Korol's'kyy: Docendo discimus (Navchayuchy, navchayusya): (do yuvileyu profesora, kandydata tekhnichnykh nauk, zaviduvacha kafedry matematyky ta metodyky yiyi navchannya Kryvoriz'koho derzhavnoho pedahohichnoho universytetu, zasluzhenoho pratsivnyka osvity Ukrayiny): biobibliohrafichnyy pokazhchyk (Volodymyr Korolskyi: Docendo discimus (Teaching, studying): (to the anniversary of professor, candidate of technical sciences, head of the department of mathematics and teaching methods of Krivoy Rog State Pedagogical University, Honored Worker of Education of Ukraine): biobibliographic index) (Kryvyi Rih State. Ped. Univ., Kryvyi Rih, 2020), http://elibrary.kdpu.edu.ua/xmlui/handle/123456789 /3045. Accessed 28 Nov 2019

13. O.I. Oleinikov, E.V. Mogilnikov, Dalnevost. matem. Journal 3, 2, 242-253 (2002)

14. Teoriya ta metodyka navchannya matematyky, fizyky, informatyky: zbirnyk naukovykh prats (Theory and methods of teaching mathematics, physics, computer science: a collection of scientific works) IX (NMetAU Publishing Department, Kryvyi Rih, 2011), http://elibrary.kdpu.edu.ua/handle/0564/737. Accessed 28 Nov 2019.

15. I.V. Lovianova, Profesiyno spryamovane navchannya matematyky u profil'niy shkoli: teoretychnyy aspekt (Theoretical and Methodological Foundations of Teaching Mathematics at ProfessionOriented School). (Chabanenko Yu. A., Cherkasy, 2014)

16. I.V. Lovyanova, D.Y. Bobylyev, in Current Status and Prospects of Mathematical Educational (SCASPEE, Budapest, 2018), pp. 37-45

17. K.V. Polgun, Dissertation, Ternopil Volodymyr Hnatiuk National Pedagogical University, 2017

18. Innovatsiyni informatsiyno-komunikatsiyni tekhnolohiyi navchannya matematyky, fizyky, informatyky u serednikh ta vyshchykh navchal'nykh zakladakh (Innovative information and communication technologies of teaching mathematics, physics, computer science in secondary and higher education institutions) (Kryvyi Rih State. ped. Univ., Kryvyi Rih, 2011). http://elibrary.kdpu.edu.ua/handle/0564/579. Accessed 28 Nov 2019.

19. N.O. Zinonos, E.V. Vihrova, A.V. Pikilnyak, Prospects of Using the Augmented Reality for Training Foreign Students at the Preparatory Departments of Universities in Ukraine. CEUR Workshop Proceedings 2257, 87-92 (2018), http://ceur-ws.org/Vol-2257/paper10.pdf. Accessed 28 Nov 2019

20. I.V. Lovyanova, D.Y. Bobylyev, in Current issues in ensuring the quality of mathematical education (SCASPEE, Budapest, 2019), pp. 39-50
21. K. Vlasenko, O. Chumak, I. Sitak, O. Chashechnikova, I. Lovianova, Espacios, 40(31), 11 (2019)

22. I. Lovianova, D. Bobyliev, A. Uchitel, Cloud calculations within the optional course Optimization Problems for $10^{\text {th }}-11^{\text {th }}$ graders. CEUR Workshop Proceedings 2433, 459-471 (2019), http://ceurws.org/Vol-2433/paper31.pdf. Accessed 28 Nov 2019

23. M.M. Volikova, T.S. Armash, Y.V. Yechkalo, V.I. Zaselskiy, Practical use of cloud services for organization of future specialists professional training Cloud Technologies in Education. CEUR Workshop Proceedings 2433, 486-498 (2019), http://ceur-ws.org/Vol-2433/paper33.pdf. Accessed 28 Nov 2019

24. K. Vlasenko, I. Lovianova, I. Sitak, O. Chumak, O. Kondratyeva, Universal Journal of Educational Research 7(9), 1892-1900 (2019)

25. M.I. Burda, N.A. Tarasenkova, O.M. Kolomiyets', I.V. Lovianova, Z.O. Serdyuk, Heometriya (profil'nyy riven') pidruchnyk dlya 10 klasu zakladiv zahal'noyi seredn'oyi osvity (Geometry (profile level) textbook for the 10th grade of institutions of general secondary education) (Orion, Cherkasy, 2019)

26. H.M. Bilousova, A.M. Kapinosov, P.I. Ul'shyn, O.Y. Chyzh, Ya.F. Hap'yuk, L.I. Kondrat'yeva, O.M. Martynyuk, S.V. Martynyuk, L.I. Oliynyk, Matematyka. Kompleksne vydannya dlya pidhotovky do DPA i ZNO (Mathematics. Complex edition for preparation for DPA i ZNO) (Pidruchnyky i posibnyky, Ternopil, 2019)

27. T.H. Kramarenko, V.V. Korolskyi, S.O. Semerikov, S.V. Shokalyuk, Innovatsiyni informatsiynokomunikatsiyni tekhnolohiyi navchannya matematyky (Innovative information and communication technologies of mathematics teaching) (KSPU, Kryvyi Rih, 2019). http://elibrary.kdpu.edu.ua/xmlui/handle/123456789 /3315. Accessed 28 Nov 2019.

28. A.E. Kiv, M.P. Shyshkina, S.O. Semerikov, A.M. Striuk, Y.V. Yechkalo, AREdu 2019 - How augmented reality transforms to augmented learning. CEUR Workshop Proceedings 2547, 1-12 (2020), http://ceur-ws.org/Vol-2547/paper00.pdf. Accessed 09 Feb 2020

29. T.H. Kramarenko, O.S. Pylypenko, V.I. Zaselskiy, Prospects of using the augmented reality application in STEM-based Mathematics teaching. CEUR Workshop Proceedings 2547, 130-144 (2020). http://ceur-ws.org/Vol-2547/paper10.pdf. Accessed 09 Feb 2020

30. T. G. Kramarenko, O. S. Pylypenko, Problemy pidhotovky uchytelia do vprovadzhennia elementiv STEM-navchannia matematyky (Problems of preparation of teacher for implementation of elements STEM-teaching mathematics). Physical and Mathematical Education 4(18), 90-95 (2018). doi:10.31110/2413-1571-2018-018-4-014 